\title{
伊豆・小笠原火山弧北端部における現在および 第四紀後期のテクトニクス
}

\author{
小山真 小* $^{*}$ \\ Late Quaternary-Present Tectonics in the Northernmost Area \\ of the Izu-Bonin Volcanic Arc \\ Masato KOYAMA*
}

\begin{abstract}
Izu Peninsula and adjacent areas, which are located on the northern tip of the Izu-Bonin volcanic arc, are characterized by intense crustal movements and volcanic activity. Many geomorphological, geological, and geophysical data were collected from this area and various tectonic models were proposed to explain them systematically. These tectonic models can be classified into two categories: models 1 and 2. While model 1 regards the area as a single tectonic province, model 2 proposes two or more tectonic provinces, which are bounded by tectonic lines. Models 1 and 2 can be classified into models $1 \mathrm{~A}$ and $1 \mathrm{~B}$, models $2 \mathrm{~A}, 2 \mathrm{~B}, 2 \mathrm{C}$, and $2 \mathrm{D}$, respectively. Model $1 \mathrm{~A}$ hypothesizes an anticlinal bend of the Philippine Sea plate, which is being generated by the subductions along the Suruga and Sagami troughs. Model $1 \mathrm{~B}$ emphasizes the crustal stress field generated by the collision of the Izu-Bonin volcanic arc with Japan arc and the slab-pull force along the Sagami trough. Since there are many local tectonic features that cannot be explained by model $1 \mathrm{~A}$ or $1 \mathrm{~B}$, models $2 \mathrm{~A}-2 \mathrm{D}$ were proposed. Model 2A divides the study area into two tectonic provinces: the northern province of compressive deformation by conjugate faults and the southern province of right-lateral shearing deformation. Model $2 \mathrm{~B}$ divides the area into the eastern and western provinces, which are defined by sharp contrasts in the geologic structure, seismicity, crustal stress field, crustal movements, focal mechanisms of earthquakes, paleomagnetic directions, and volcanic activity. Many observations support the validity of the model 2B tectonic provinces. Model $2 \mathrm{C}$ introduces the hypothesis that the Izu-Bonin arc is being fractured into the inner and outer arcs because of a contrast in buoyancy. The existence of the estimated model $2 \mathrm{C}$ fracture, West Sagami Bay Fracture, is still under debate. Model 2D regards the Higashi-Izu monogenetic volcano field, located in the eastern Izu Peninsula, as a field of crustal spreading. Model 2D proposes a key to understanding a sharp contrast in tectonic features between the eastern and western provinces of model $2 \mathrm{~B}$ as well as the complex geometry of the Philippine Sea slab beneath the Japan arc.
\end{abstract}

* 静岡大学教育学部地学教室

* Faculty of Education, Shizuoka University 


\section{I. はじめに}

伊豆。小笠原弧の北端部にある伊豆半島とその 周辺陸域・海域は，プレート境界の近傍に位置す る活発な地款活動・火山活動の場として知られて いる。伊豆・小笠原弧北端部における現在および 第四紀後期のテクトニクスは，伊豆・小笠原弧と 本州弧の衝突（あるいは浮揚性沈み込み），なら びに駿河・相模両トラフに拈けるフィリピン海プ レートの沈み込みという2つの現象の重畳によっ て大枠が支配されているとみられている（たとえ ば, Nalsamura et al., 1984 ; Ukawa, 1991)。し かし, 詳細なプレート幾何学や力学的状態, およ び具体的な個々の地学現象の位置づけについては, これまで数多くのモデルが提唱され，研究者間の 議論がーづけられている。

本論では，伊豆・小笠原弧北端部における現在 および第四紀後期のテクトニクスを統一的に説明 しょうと:したモデルのうち，プレートテクトニク スの枠組みの中で十分な考察と吟味がなされてい るものについて分類を行ない，各モデルの特徴と 問題点の総括を試みる。このような作業・考察を 通じて伊豆・小笠原弧北端部のテクトニクスに関 する理解を深めることが，この地域に生じる火 山・地震をはじめとする様々な地学現象の原因を 知り,ざらには将来予測をするための基礎となる であろう。

\section{II. 研 究 史}

プレートテクトニクスを念頭においた伊豆・小 笠原弧北端部のテクトニクスの研究は，杉村 （1972）に始まると言ってよい。杉村の研究は, フィリピン海プレートと本州側のプレートの境界 が陸上のどこを通過するかという問題に主眼がお かれた。そこには，伊豆・小笠原弧が本州弧を 「北西方に押している」といら認識が呈示されて いるが，「衝突」といら言葉はみられない。伊豆地 塊と本州の相互作用を衝突 (collision) といら言 葉で初めて表現したのは, Matsuda (1978) であ る。その後, 伊豆・小笠原弧北端部のテクトニク スに関する研究は，およそ $1 \mathrm{Ma}$ におきた伊豆・
小笠原弧と本州弧の衝突過程に主眼をおいた地質 学的研究と, 伊豆 - 小笠原弧北端部の現在の状態 をどう理解するかという総合的・学際的研究に二 極分化していく。本論は，この後者をあつかう。

1974年伊豆半島沖地震を発端とする伊豆周辺の 地款活動の高まりの中で, 伊豆・小笠原弧北端部 の現在の状態をどう理解するかという問題が関心 をよび，エポックメイキングな討論会「伊豆半島 の変形と応力場」が1979年 8 月に行なわれた。そ の成果は, 月刊地球1980年 2 月号「伊豆半島のテ クトニクス」としてまとめられている。そこでは, プレートの曲りによって伊豆周辺のテクトニクス を総合的に理解しようとする中村 (1980), 岩脈 法によって伊豆半島を東と西の応力区に分けた中 野ほか (1980), 伊豆周辺を北部の衝突带と南部の トランスフォームベルトとに分けた石橋（1980）, 伊豆・小笠原弧北部を外弧と内弧とに分けて考え る貝塚（1980）など, のちの重要なモデルの原型 となる考え方が登場ないしは強調されている。

プレートの曲りを重視した中村（1980）のモデ ルは, その後中村・島崎 (1981) を経て, Nakamura et al. (1984) のモデルへと集大成されて いく。また, 中野ほか (1980) の考え方は, 小林 (1980), 塚原・池田（1983）などへ継承される一 方, 石橋 (1980) の考え方の基本は Ida (1991) な どに継承された。また，貝塚（1980）の考え方は 貝塚（1984）に集大成され，さらに伊豆内弧と外 弧の裂け目として西相模湾断裂を導入した石橋 （1988）によって精密化させられた。

1980年代以降には様々な調查や観測の精度が高 まり，プレートの曲りよりも衝突現象のつくる応 力場を重視する Ukawa（1991）のモデルや, 火 山活動の歴史と特徵, 上部地殼の構造, プレート 幾何学に関する考察を加えた Koyama and Umino (1991), 小山 (1993), 山岡ほか (1994) など のモデルが登場している。

\section{III. モデルの分類}

これまで提案された伊豆・小笠原弧北端部全体 をあつからテクトニックモデルは，

モデル 1 : 伊豆・小笠原弧北端部を基本的には 
単一の構造区（tectonic province）とみなし， 内部に大きな構造境界を考えないモデル

モデル 2 : 伊豆・小笠原弧北端部を複数の構造

区の集合体とみなし，構造区ごとにやや異な

るテクトニクスを考えるモデル

の 2 つ大きく区分できる（表 1 )。

これらのうち，同じモデル 1 に属するモデルの 中にも，対照的な 2 つ考え方がある。すなわち，

モデル $1 \mathrm{~A}:$ 相模・駿河両トラフでの沈み込

みとそれにともならプレートの曲りによる張

力を重視するモデル (plate bending モデル)

(Nakamura et al., 1984.)

モデル $1 \mathrm{~B}$ : 伊豆・小笠原弧と本州弧の衝突に

よる圧縮力と，相模トラフから沈み込むプ

レートのスラブプルによる張力とがあいま

ってテクトニクスを支配するとみるモデル

(collision-slab pull モデル) (Ukawa, 1991)

の 2 種類である。

また，モデル 2 に属するモデル中にも，

モデル $2 \mathrm{~A}$ : 伊豆半島の北部（北東部）と南部

（南西部）で異なる構造区を考えるモデル（石

橋，1977，1980; Somerville, 1978 ; Ida,

1991など)

モデル $2 \mathrm{~B}$ : 伊豆半島を 北北東一南南西に縦断

する構造線の東西で異なる構造区を考えるモ

デル（中野ほか，1980；小林，1980；塚原・

池田，1983; 星野， 1984 ; Tsukahara and

Ikeda, 1987 ; Kikawa et al., 1989 ; Koyama and Umino, 1991)

モデル $2 \mathrm{C}$ : 伊豆・小笠原弧北端部を伊豆内 弧

と伊豆外弧の 2 つの構造区に分けて考えるモ

デル (貝塚, 1984 ; 石橋, 1988 ; Koyama and

Umino, 1991 ; 小山, 1993)

モデル $2 \mathrm{D}$ : 東伊豆単成火山地域を地殼の拡

大域，丹那断層とその北方延長を地款拡大に

ともなうトランスフォーム断層としてとらえ， 伊豆半島北東部含む一帯を一種のマイクロ プレートとして考えるモデル（小山，1993；

山岡ほか，1994)

の 4 種類がある（表 1 ）。Koyama and Umino (1991) はモデル 2 B と 2C, 小山（1993）はモデ
ル $2 \mathrm{C}$ と $2 \mathrm{D}$ を組み合わせたモデルを考えている。 なお，上記には含めていないが，伊豆・小笠原 弧北端部のうち，とくに大地震の発生の場である その北縁の境界部を主としてあつかい，境界の場 所や地震テクトニクスを考察したモデルもいくつ か存在する（多田，1977；Tada and Sakata， 1977 ; 松田，1985，1993 ; 山崎, 1985，1993 ; 大 河内， 1990 ; 石橋，1992など)。

このように伊豆・小笠原弧北端部のテクトニク スを統一的に説明しようとしたモデルは多い。し かし，すべてのモデルが共通のデータの上に立脚 し，同程度の精度の議論を行なっているわけでは なく，重視するデータの種類や，どの程度細かな 構造・特徴まで説明しようとするかが暴なってい る（表1）。同じモデルとして分類された中でも， 個々のモデルの精密さや細部の様相・考え方には 幅がある。

\section{IV. 各モデルの特徵と問題点}

\section{1）モデル 1}

モデル1は，伊豆・小笠原弧北端部において上 部地殼内でおきる地震の $\mathrm{P}$ 軸（あるいはT軸）方 位が扇型の分布をもつこと（図 1，2）に代表さ れる様々な観測事実を，単一の構造区を用いたモ デルによって統一的に説明したものである。

モデル $1 \mathrm{~A}$ は，相模・駿河両トラフでのプレ 一ト沈み込みが伊豆・小笠原弧北端部にプレート の曲りをむたらし，それに起因するトラフ軸と直 交する方向の引張力が最小主応力軸方位の扇型分 布を発生させたと考える (Nakamura et al., 1984: 図 1)。そして, このプレートの曲りに起 因する引張場に，伊豆地塊と本州の衝突による北 西-南東方向の圧縮力が重畳した結果，中間主応 力軸が垂直となり，伊豆・小笠原弧北端部を支配 する横ずれ断層型の応力場が形成されたと説明し ている。

Ukawa（1991）は，駿河トラフ近傍のフィリピ ン海プレート内部に南北性の $\mathrm{P}$ 軸をもつ逆断層型 の地震が生じていることを見出した。このような 地震は駿河トラフでの沈み込みに起因するプレー トの曲りとは不調和であり，モデル $1 \mathrm{~A}$ ではう 
表 1 伊豆・小笠原弧北端部における現在および第四紀後期の テクトニクスに関する主要なモデル

\begin{tabular}{|c|c|c|c|}
\hline 分類 & モ デル & 主なよりどころとするデータ & モデルの特徴 \\
\hline $1 \mathrm{~A}$ & $\begin{array}{l}\text { Nakamura et al., } \\
1984\end{array}$ & $\begin{array}{l}\text { 発震機構, 地形, 地質, 震源分布, 活 } \\
\text { 断層, 測地データ, スラブ幾何学 }\end{array}$ & プレートの曲り \\
\hline $1 \mathrm{~B}$ & Ukawa, 1991 & 発震機構, スラブ幾何学, モデル計算 & 衝突とスラブプル \\
\hline $2 \mathrm{~A}$ & 石橋, 1977,1980 & $\begin{array}{l}\text { 活断層, 最近の主な地震, 海底地形, } \\
\text { 関東地震の震源断層モデル }\end{array}$ & $\begin{array}{l}\text { 伊豆トランス } \\
\text { フォームベルト }\end{array}$ \\
\hline $2 \mathrm{~A}$ & Somerville, 1978 & $\begin{array}{l}\text { 活断層, 最近の主な地震, 測地データ, } \\
\text { プレート運動収支計算 }\end{array}$ & $\begin{array}{l}\text { 衝突と伊豆地塊の } \\
\text { 内部変形 }\end{array}$ \\
\hline $2 \mathrm{~A}$ & Ida, 1991 & $\begin{array}{l}\text { 活断層, 応力場, 最近の主な地殼活動, } \\
\text { モデル計算 }\end{array}$ & $\begin{array}{l}\text { 衝突から沈み込み } \\
\text { 带への漸移 }\end{array}$ \\
\hline $2 \mathrm{~B}$ & $\begin{array}{l}\text { 中野ほか } 1980 ; \\
\text { 小林, } 1980\end{array}$ & $\begin{array}{l}\text { 岩脈法 ·側火山分布・発震機構・活断 } \\
\text { 層による応力方位 }\end{array}$ & $\begin{array}{l}\text { tectonic stress } \\
\text { province }\end{array}$ \\
\hline $2 \mathrm{~B}$ & $\begin{array}{l}\text { 塚原・池田,1983； } \\
\text { Tsukahara and } \\
\text { Ikeda, } 1987\end{array}$ & $\begin{array}{l}\text { 現場応力測定・発震機構・活断層・側 } \\
\text { 火山分布による心力方位 }\end{array}$ & 地殼応力区 \\
\hline $2 \mathrm{~B}$ & $\begin{array}{l}\text { Kikawa et al., } \\
1989\end{array}$ & 第四紀火山の古地磁気 & $\begin{array}{l}\text { 伊豆半島の } \\
\text { differential tilting }\end{array}$ \\
\hline $2 \mathrm{C}$ & 貝塚, 1984 & $\begin{array}{l}\text { 地形, 鮮新〜更新世の地史, 第四紀地 } \\
\text { 殼変動, 火山分布, スラブ幾何学, 活 } \\
\text { 断層 }\end{array}$ & $\begin{array}{l}\text { 伊豆内弧バー・外 } \\
\text { 弧バー }\end{array}$ \\
\hline $2 \mathrm{C}$ & 石橋, 1988 & $\begin{array}{l}\text { 関東地震時の上下変動, 関東地震の震 } \\
\text { 源断層モデル, スラブ轹何学, 海底地 } \\
\text { 形地質, 歴史地震, 中新世以来の地史 }\end{array}$ & 西相模湾断裂 \\
\hline $\begin{array}{l}2 \mathrm{~B} \\
+2 \mathrm{C}\end{array}$ & $\begin{array}{l}\text { Koyama and } \\
\text { Umino, } 1991\end{array}$ & $\begin{array}{l}\text { 地形, 地質構造, 地殼構造, 応力方位, } \\
\text { 第四紀地款変動, 古地磁気, 活断層, } \\
\text { 震源分布, 火山分布, 火山活動の性質 }\end{array}$ & $\begin{array}{l}\text { 西相模湾断裂, } \\
\text { block rotation, } \\
\text { volcanotectonic } \\
\text { province }\end{array}$ \\
\hline $\begin{array}{l}2 \mathrm{C} \\
+2 \mathrm{D}\end{array}$ & 小山, 1993 & $\begin{array}{l}\text { 地形, 地質構造, 地殼構造, 応力方位, } \\
\text { 第四紀地殼変動, 古地磁気, 活断層, } \\
\text { 震源分布, 火山分布, 火山活動の性質 }\end{array}$ & $\begin{array}{l}\text { 西相模湾断裂, } \\
\text { block rotation, 東 } \\
\text { 伊豆地垛拡大域, } \\
\text { マイクロプレー } \\
\text { ト, 丹那一平山ト } \\
\text { ランスフォーム断 } \\
\text { 層 }\end{array}$ \\
\hline $2 \mathrm{D}$ & 山岡ほか, 1994 & $\begin{array}{l}\text { スラブ幾何学, プレート運動収支, 測 } \\
\text { 地データ, 震源分布, 活断層, 火山分 } \\
\text { 布, 火山活動の性質 }\end{array}$ & $\begin{array}{l}\text { 東伊豆一伊豆大島 } \\
\text { 地殼払大域, 丹那 } \\
\text { 一平山トランスフ } \\
\text { ォーム断層 }\end{array}$ \\
\hline
\end{tabular}

左からモデルの分類記号, 各モデルが主なよりどころとしたデータの種類, キーワードで表 したモデルの特徵. 詳細は本文参照. 


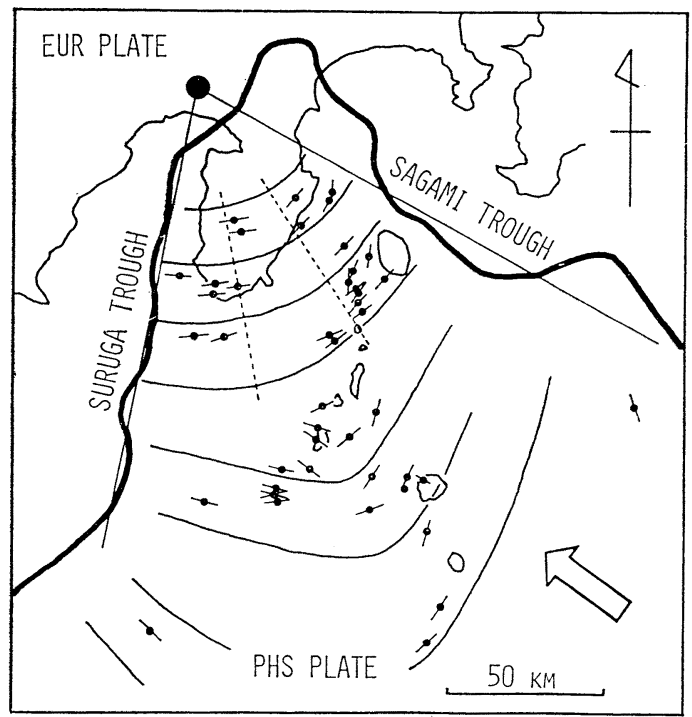

図 1 Nakamura et al. (1984) による伊豆・小笠 原弧北端部のモデル（モデル 1A）

駿河・相模両トラフ下への沈み込みにともな らプレートの曲りが，テクトニクスを支配し ていると考えた. 上部地款内地震のT軸方位 と, それらをなめらかに結ぶ応力軌跡の解釈 が示されている. 白矢印はユーラシアプレー ト (EUR) に対するフィリピン海プレート (PHS) の相対運動方向.
まく説明できない。また，本州に対するフィリピ ン海プレートの進行方向を考えると，相模卜ラフ 軸でのプレート相対運動はほとんど横ずれ成分と 考えられるため, 沈み込みに先立つプレートの曲 りは累積しにくく緩和しやすいと考えられる。よ って，たとえプレートの曲りが生じたとしても， それに起因する引張場が現在も持続しているかど らか疑問である(Ukawa，1991)。

Ukawa（1991）は，簡単な力学計算にもとづ き，伊豆地塊北縁でおきる本州との衝突に起因す る圧縮応力場が，相模トラフから沈み込むプレー トのスラブプルカとあいまって，現在みられる応 力軸の扇型分布をつくり得ることを示した（モデ ル $1 \mathrm{~B}$ : 図 2)。モデル $1 \mathrm{~B}$ に従えば，駿河トラフ 近傍のフィリピン海プレート内部に生ビる南北性 の $\mathrm{P}$ 軸をもつ逆断層型地震は, 伊豆地塊と本州と の衝突に起因する地震として説明できる。また， スラブプルによる引張力を採用することによって， プレートの曲りといら現象を無理に考えなくても よいことが示されたわけである。

モデル $1 \mathrm{~A} ・ 1 \mathrm{~B}$ は，伊豆・小笠原弧北端部全 体を大局的に支配するテクトニクスを知ろうとす
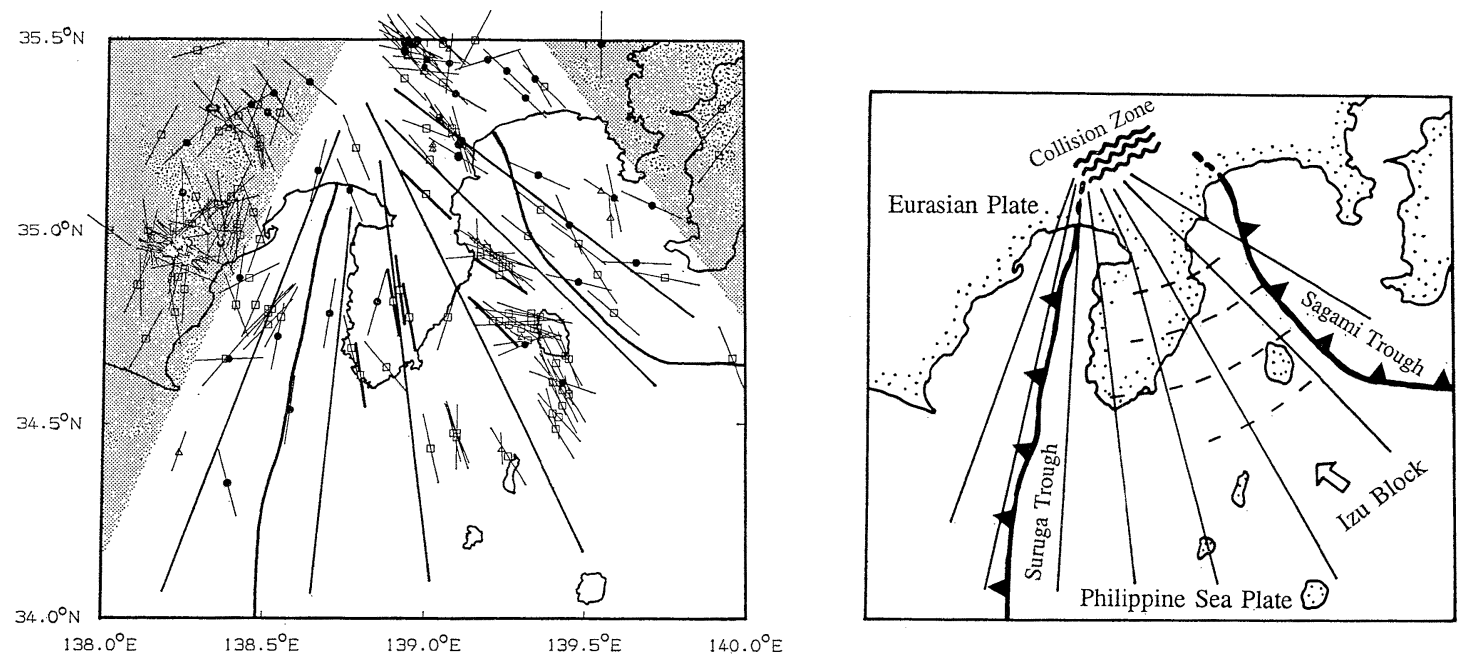

図 2 伊豆半島周辺で起きる地震の発震機構と Ukawa（1991）による解釈（モデル 1 B） 左図: Ukawa (1991) による上部地殼内地震のP軸方位と発震機構（口: 横ずれ断 層型， $\Delta$ : 正断層型， - 逆断層型). $\mathrm{P}$ 軸方位をなめらかに結ぶ応力軌跡の 解釈が放射状の実線で示されている. 院影をつけていない部分のデータが，フ イリピン海プレート内の忘力状態を表すと考えられている.

右図 : 左図応力軌跡の解釈 (Ukawa，1991). 伊豆・小笠原弧と本州弧の衝突による 圧縮力と，相模トラフから沈み込むプレートのスラブプル力を重視している. 
る考えおであり，西相模湾断裂のような局所的な 構造は，副次的なゆらぎと考える。たとえば， Nakamura et al. (1984) は，石橋（1988）によ って西相模湾断裂の南端部としてみなされた海底 崖に断贋の存在を認めながらも，それをプレート 内部の副次的な構造と考えて重視していない。

しかしながら，伊豆・小笠原弧北端部において は高密媵高精度の観測データが集積されており, 様々な観測值の局所的なゆらぎについても精度の 高い議諭が可能となっている。また, 個々の地震 断層や火山噴火のテクトニクスを考える上で, 局 所的・副次的なテクトニクス場のゆらぎを無視で きない塨合がある。モデル 1 は基本哲学として重 要であるが，たとえば東伊豆地域でおきる群発地 震や地款変動のメカニズムのような局所的な個々 の問題を考えるにあたっては，おのずと適用限界 があるように思う。

\section{2) モ:デル $2 \mathbf{A}$}

単一構造区のモデル 1 に対し, 複数の構造区を 設定しでより細部の現象まで説明しようとする立 場をとる゙が，モデル 2 である。モデル 2 は，構 造区境界の引き方と構造区を支配するテクトニク スの解橎の仕方によって, モデル $2 \mathrm{~A} \sim 2 \mathrm{D}$ の 4 つに分けられる(表 1 )。

モデル $2 \mathrm{~A}$ は，伊豆・小笠原弧北端部のうち， とくに嘲豆半島とその周辺海域に注目し, その地 域の北部（または北東部）と南部（または南西 部）の特徵の違いに基整をおいたモデルである。 モデル $2 \mathrm{~A}$ は, 北部を本州弧との衝突に起因す る圧縮変形の場, 南部を石廊崎断層をはじめとす る複数の)右横ずれ断層による shearing が支配す る場と考える（たとえば，石橋，1980：図 3 )。

石橋 (1980) は，プレート力学境界断層である 相模トラフスラストのつづきとして西相模湾スラ ストを老え, 西相模湾スラストと駿河卜ラフを結 ぶ幅をもつトランスフォーム境界（伊豆トランス フォームベルト）が伊豆半島南部を通過すると考 えた（四3）。これに対し，Somerville（1978） と Ida (1991) は西相模湾スラストをプレートカ 学境界断層とは考えずに, 伊豆半島南部をフィリ ピン海プレートの内部変形帯としてとらえた。伊

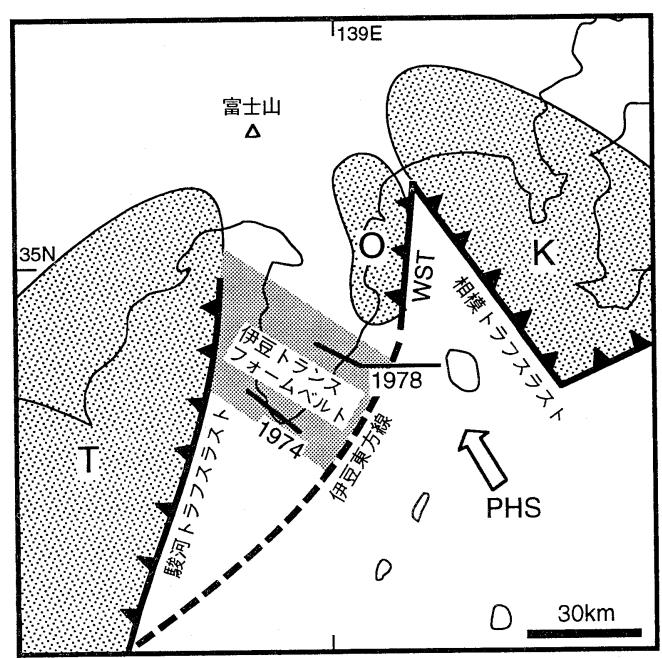

図 3 モデル $2 \mathrm{~A}$ の例

石橋（1980）による伊豆・小笠原弧北端部のモデル の図を簡略化したもの. 西相模湾スラスト (WST) をプレート沈み込み境界, 伊豆半島南部を幅のある トランスフォーム境界（伊豆トランスフォームベル ト）として解釈した. 陰影をつけた領域 $\mathrm{T}, \mathrm{O}, \mathrm{K}$ は，それぞれのスラストで生じる地震の震源域。実 線 1974 と 1978 は, それぞれ1974年伊豆半島沖地震, 1978年伊豆大島近海地震の震源断層. 矢印 PHS は, 東北日本に対するフィリピン海プレートの相対運動 方向.

豆半島北縁の衝突帯においてはフィリピン海プレ ートの北西進が妨げられるため, 南海トラフ下へ 容易に沈み込むフィリピン海プレートとの間にプ レート相対速度の差が生じることになり，この速 度差に起因する剪断歪みの解消帯として伊豆半島 南部の活断層帯が生じたという考え方である。な お，明確な構造区分を行なってはいないが，石廊 崎断層とその延長（図 4) を一種のプレート内断 裂としてとらえ断裂の南北でテクトニクスが異な ることを主張した茂木（1977）のモデル，および フィリピン海プレートが伊豆半島周辺において 3 つにスプリットするといら笠原（1985）のモデル も, 伊豆半島南部における右横ずれ変形を重視す る点でモデル $2 \mathrm{~A}$ の一種と言えるかもしれない。

石橋 (1980) は, 伊豆トランスフォームベルト の南東縁を西相模湾スラストの南方延長 である 「伊豆東方線」と考え，ここに西相模湾スラスト と同様の西傾斜スラストが存在する可能性を述べ 


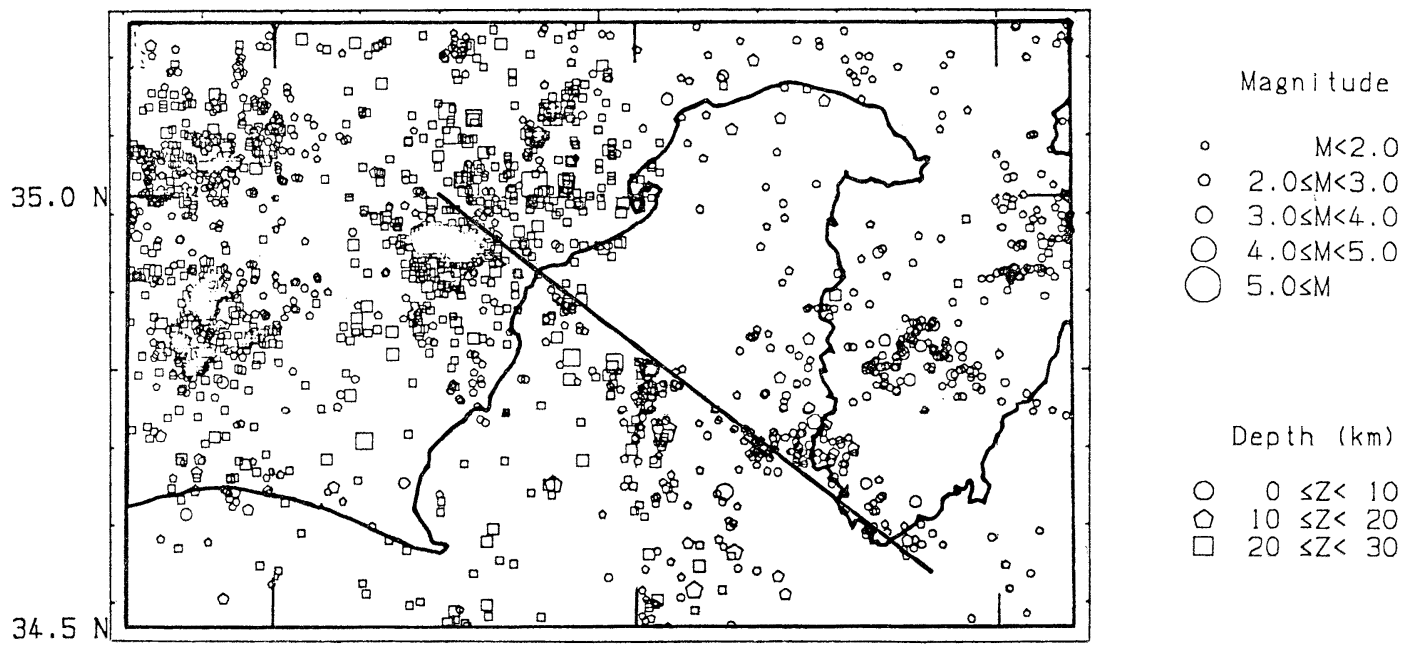

図 4 駿河湾とその周辺における震源分布 (Ukawa et al., 1988) 1980 1986年の間に生じた $30 \mathrm{~km}$ より浅いもの. 茂木（1977）の唱えた 断裂線の位置を実線で示した.

ている。かつてこの「伊豆東方線」が，駿河トラ フスラストとともに二重のスラスト構造をなすプ レート力学境界断層として重視されたことがあっ た（石橋，1977; 藤井，1977など)。しかし，断 層地形が不明瞭なこと，スラストの存在を裏づけ る地震活動が知られていないこと，1978年伊豆大 島近海地震の震源断層が伊豆東方線と交差するこ と, 当初は伊豆東方線沿いのクリープに起因する との考えもあった伊豆半島東部の地殼隆起が火山 活動起源であることが明確になったことなどから， 1980年代以降に堤唱されたほとんどのモデルは伊 豆東方線の存在を重視していない。

モデル $2 \mathrm{~A}$ の難点は, 現実の地質データをは じめとする多くの観測事実と調和的でない点であ る。モデル $2 \mathrm{~A}$ において伊豆半島南部を支配す るとされる右横ずれ型の shearing が, 実際に駿 河トラフ軸付近まで達している証扰は見つかって いない。Ukawa（1991）によれば, 駿河湾海域の フィリピン海プレート内部で生じる地震の発震機 構は南北ないしは北東一南西の $\mathrm{P}$ 軸方位をもつ逆 断層あるいは横ずれ断層型であり (図 2 左), モ デル $2 \mathrm{~A}$ から期待される北西一南東の $\mathrm{P}$ 軸方位を もつ横ずれ断層型とは異なる。また, 次節で述べ
るように1974年伊豆半島沖地震や1978年伊豆大島 近海地震の余震分布は, モデル $2 \mathrm{~B}$ の昌える伊豆 半島を縦断する構造線付近が北西限となっている。

茂木（1977）は，石廊崎断層から駿河トラフを 横断して静岡西方に達するフィリピン海プレート 内断裂を推定し，その存在の主な証拠として断裂 線に沿う線状の震源分布, 駿河トラフ軸および静

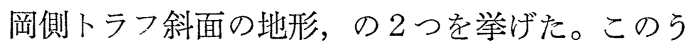
ち震源分布については, その後増えたデータから, 茂木の推定した断裂線付近を境にした駿河湾海域 の地震活動度の差が指摘されている（Ukawa et al., 1988：図 4)。断裂線北側の低い地震活動度 は, 駿河トラフ軸に直交する方向の圧縮応力の増 加にともなうフィリピン海プレート内の差応力の 低下が原因とされ (Ukawa, 1991)，断裂の存在を 直接反映するものではない。また，茂木（1977） が断裂存在の証拠として指摘した駿河トラフ軸地 形の屈曲は，伊豆側卜ラフ斜面上にある隆起帯が 駿河トラフ下へ沈み込むことによって作られた狭 窄部 (石花海ゴージ) であることが深海潜水艇を 用いた地質調査によってわかっている（小山ほか， 1992)。また，茂木（1977）の指摘した駿河トラ フ静岡側斜面の南北の地形差も, この隆起帯の沈 
み込みに起因するものとして説明可能である。石 花海ゴージ付近の駿河トラフ伊豆側斜面上に広く 分布する第四紀の石灰質砂岩層は，全体が西方の トラフ軸に向かって緩やかに傾斜しており，大き な断裂構造の存在は認められていない（小山ほか, 1992)。

恒石・杉山（1978）は，静岡市西方の第三系高 草山層群の分布に右横ずれ変位を与えている断層 を発見し，それが茂木の提唱した断裂線上にある ことから断裂を反映した断層と考え，「駿豆断層」 と命名した。しかし，その後の詳細な地質調查に よって, 問題の断層はまわりの裮曲構造と調和的 な分布を示す局所的な断層であり，主要な活動時 期も鮮新世末〜更新世初期と古いことが判明して いる（杉山ほか，1982）。

かりに，モデル $2 \mathrm{~A}$ から期待されるよらな伊 豆半島南部における右横ずれ型の shearing が過 去数十万年にわたってっづいてきたとしたら， shearing にともなう歪を解消する断層の累積右 横ずれ変位は相当量になると考えられる。しかし， それを支持する地形・地質学的事実はこれまで見 つかっていない。たとえば，石廊崎断層に沿ら変 位は地質図表現としては無視できるほど小さいこ とがよく知られている (Yamada, 1977 ; 狩野, 1983)。伊豆半島南部の主な活断層の変動地形か ら推定された活動度は $0.01 \sim 0.1 \mathrm{~cm} /$ 年であり (星野ほ放, 1977), 伊豆半島周縁のプレート力学 境界域を構成する入山瀬断層や国府津-松田 断 層 などの主:要活断層の活動度 $(0.2 \sim 0.8 \mathrm{~cm} /$ 年 : Yamazaki，1992）より一桁小さい。伊豆半島の 地質図 (小山, 1988) からも, 大きな右横ずれ断 層が伊豆半島中部〜南西部地域を北西一南東方向 に横切っている証拠を認めることはできない。た とえば，次節で述べる湯ケ島一松崎構造線の一部 をなす門野断層は, 松崎町南部から天城峠西方ま で $13 \mathrm{~km}$ にわたって追跡できる直線的なトレース をもつ。

以上のことから，伊豆半島南部から駿河トラフ 軸付近にかけての地域を右横ずれ型の shearing が支配する場とみるモデル $2 \mathrm{~A}$ の考え方には， 納得できない点が多い。なお，モデル $2 \mathrm{~A}$ に属す

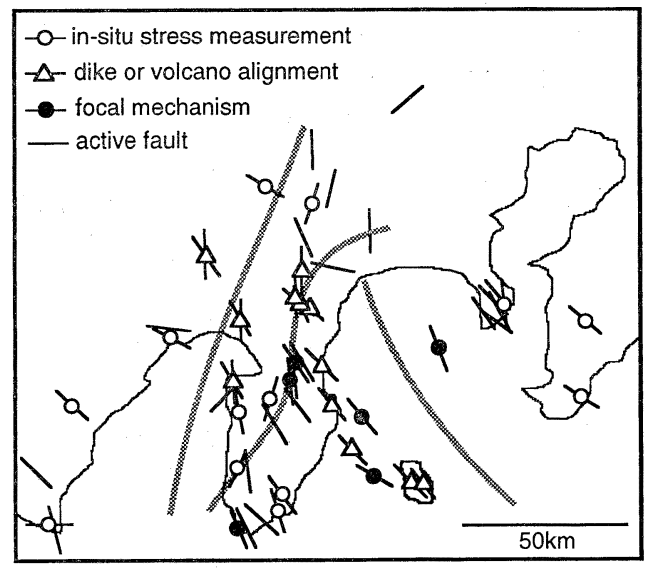

図 5 モデル $2 \mathrm{~B}$ の例

Tsukahara and Ikeda (1987) による伊豆・小笠原 弧北端部の構造区分. 短実線 は水平最大圧縮軸方 位. 現場応力測定 $(O) \cdot$ 岩脈または火山配列 $(\Delta) \cdot$ 地震の発震機構 (・)・活断層（無印）のそれぞれ のデータから求めたもの. 応力方位の急変線（灰色 太実線）を構造区境界と考㿝た。データの出典は塚 原・池田（1983）を参照.

るモデルのうち, 石橋 $(1977,1980)$ のモデルは その後撤回され，西相模湾断裂の概念を導入した 石橋（1988）のモデル（モデル2C）となってい る。

\section{3） モデル $2 \mathrm{~B}$}

モデル $2 \mathrm{~B}$ に分類されるモデルは，伊豆半島内 における地款応力方位をはじめとする様々な観測 データの地域的不連続性を説明するために提唱さ れた。中野ほか（1980） は伊豆半島に分布する 岩脈の方位から，塚原・池田 (1983), 星野 (1984), Tsukahara and Ikeda（1987）は現場応 力測定・活断層の走向などから，伊豆半島を北北 東一南南西に縦断する地殼応力方位の急変線を見 出し，その線を境として伊豆半島を 2 つの構造区 に区分した (図 5)。Kikawa et al. (1989) は, 第四紀火山の古地磁気偏角が上述の構造線付近を 境として伊豆半島の西部と東部で系統的に異なる ことを見出し，2つの構造区の存在を支持した。

Koyama and Umino (1991) も地質データから ほぼ同じ位置に構造線を推定し，そこを境とする 地殼構造 - 地殼応力方位 - 地震活動度 - 古地磁気 方向・火山活動の性質などの違いから伊豆半島を 


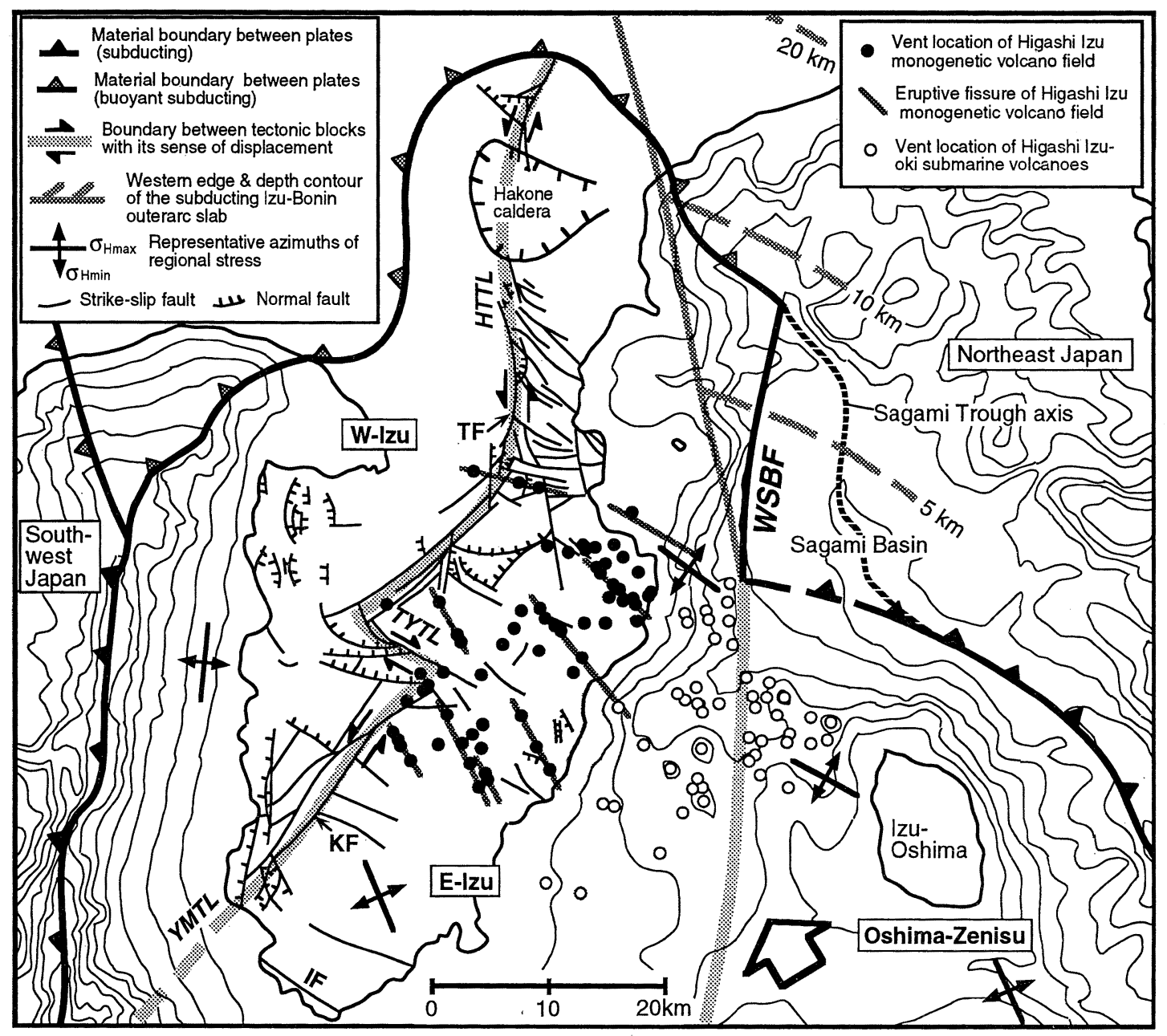

図 6 伊豆・小笠原弧北端部の地形・地質・地球物理学的特徵と構造区分（モデル $2 \mathrm{~B}+2 \mathrm{C}$ )

Koyama and Umino（1991）の図を簡略化したもの. 東伊豆単成火山群の噴火割れ目の位置については，そ の後の知見を加えて修正してある. 伊豆・小笠原弧北端部を西伊豆 $(\mathrm{W}-\mathrm{Izu}) \cdot$ 東伊豆 $(\mathrm{E}-\mathrm{Izu}) \cdot 大$ 島-銭洲 (Oshima-Zenisu) の 3 構造区に分けた. WSBF : 西相模湾断裂. TF : 丹那断層. KF : 門野断層. HTTL, TYTL, YMTL は本文参照. 白矢印は，東北日本に対するフィリピン海プレートの相対運動方向. 等深線の 間隔は $250 \mathrm{~m}$.

\section{2 つの構造区に分けた（図6）。}

これらモデル $2 \mathrm{~B}$ の主張する構造区境界の存 否は, モデル $2 \mathrm{~B}$ や後述のモデル $2 \mathrm{D}$ の是非に かかわる根本的な問題であるので，ここでやや詳 しく述べる。構造区境界の存在の根拠として考え られている観察事実および解釈を以下に列挙する。 地凯応力方位 : 伊豆半島においては, 上部地殼 内でおきる地震の $\mathrm{P}$ 軸方位や現場応力測定などの データから求まる地殼応力方位が西半部（水平最
大圧縮軸方位がほぼ南北）と東半部（水平最大圧 縮軸方位がほぼ北西-南東〜北北西一南南東）とで 系統的に異なる（図 2 左，図 5 )。この応力方位 の変化については，ほぼ連続的に扇型を描くよう に変化するという見方（モデル 1 : 図 1，2）と， 半島をほぼ北北東一南南西に縱断する境界を境と して不連続的に変わるとする見方（モデル $2 \mathrm{~B}$ ： 図 5 ）とがあるが，データの豊富な塚原・池田 (1983) や Tsukahara and Ikeda (1987) から判 
断して，不連続的に変化するとみる方が自然であ るように思う。

地質構造 : 伊豆半島内（箱根火山地域までを含 めて）には，起源の異なる異質な地質体同士が接 している例（たとえば，伊豆地塊の北縁で丹沢山 地の火山岩類と足柄層群とが神繩断層で接するよ らな例）はなく，伊豆・小笠原火山弧起源の物質 のみが分布する（小山，1986，1988）。乙かしな がら，伊豆半島内には活断層を含む数多くの断層 が存在する。Koyama and Umino (1991) は, 伊 豆半島内に 3 列の断層密集帯を認識し, それぞれ 平山一棚場構造線 (HTTL), 棚場一湯ケ島構造線 (TYTL), 湯尔島-松崎構造線 (YMTL) と呼ん だ（図 6 )。HTTL, TYTL, YMTL の 3 つの構 造線は全体として伊豆地塊をほぼ北北東一南南西 に分断しており，モデル $2 \mathrm{~B}$ の唱える東伊豆/西 伊豆構造区境界の位置とほぼ一致する。

活断層・発震機構: 伊豆半島内に分布する活断 層のほとんどは水平方向の変位が卓越する横ずれ 型であるが，モデル $2 \mathrm{~B}$ の西伊豆構造区に含まれ る半島の西半部には正断層も存在する（星野ほか, 1978 ; 図 6 )。一方, 上部地殼内でおきる地震の 発震機構は，伊豆半島およびその周辺海域の全域 において横ずれ型が卓越しているが，西伊豆構造 区とその沖合の駿河湾海域には逆断層型も存在す る(Ukawa，1991：図 2左)。

地震活動度 : ここ 60〜 70年間の伊豆半島とその 周辺に扮ける地震分布をみると, 地震活動度はモ デル 2 B の西伊豆構造区で低く, 東伊豆構造区で 高いことが明瞭である（たとえば，吉田，1985：

図 7 )。

地殼構浩 : 屈折法地震探查によって明らかにさ れた伊豆半島の地震波速度構造（Asano et al., 1982）をみると，東伊豆/西伊豆構造区境界の一 部にあたる HTTL を横切る三島一下田測線の修 善寺付近仁大きな不連続がみられ，HTTL 付近 より北側に存在する $5.0 \mathrm{~km} / \mathrm{s}$ 層が南側には存在 しないこょがわかる。また，この付近より北側に ある $6.1 \mathrm{~km} / \mathrm{s}$ 層には認められない垂直方向の地 震波速度勾配が，南側にある $5.5 \mathrm{~km} / \mathrm{s}$ 層には認 められるという (Asano et al., 1982)。

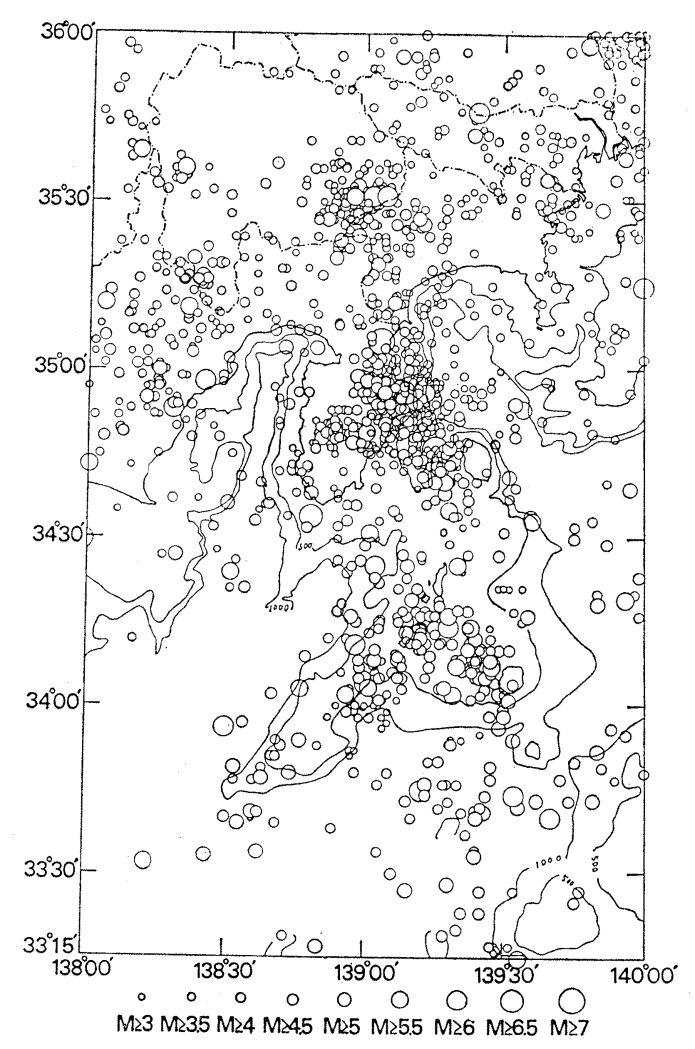

図 7 伊豆半島とその周辺に扮ける地震分布 1926 1982年の期間内の深さ $40 \mathrm{~km}$ 以浅のもの. (吉田, 1985)

測地学的変動 : 伊豆半島の主として東部におい て, 現在までの総隆起量が多い場所で $40 \mathrm{~cm}$ に達 する隆起が1975年以来つづいている（たとえば， 石井，1989，1992）。この隆起が進行している地 域は，ほぼ東伊豆構造区内部だけに限られるよう に見える。とくに，1980年頃までの測地測量結果 をみると，隆起域の西端はちょうど修善寺付近に おける東伊豆/西伊豆構造区境界の位置に一致す るように見える (Tada and Asano, 1983 ; 小山, 1988 ; Koyama and Umino, 1991)。

最近の主な地震の特徵 : 1978年伊豆大島近海地 震の余震は，本震の震源域である伊豆大島西方海 域から出発して伊豆半島内部を北西に向かって分 布を広げ，東伊豆/西伊豆構造区境界の一部にあ たる YMTL 付近に達した後, YMTL に沿って 南西方向に分布を広げたように見える（津村ほか， 1978 : 図 8)。1974年伊豆半島沖地震の余震分布 

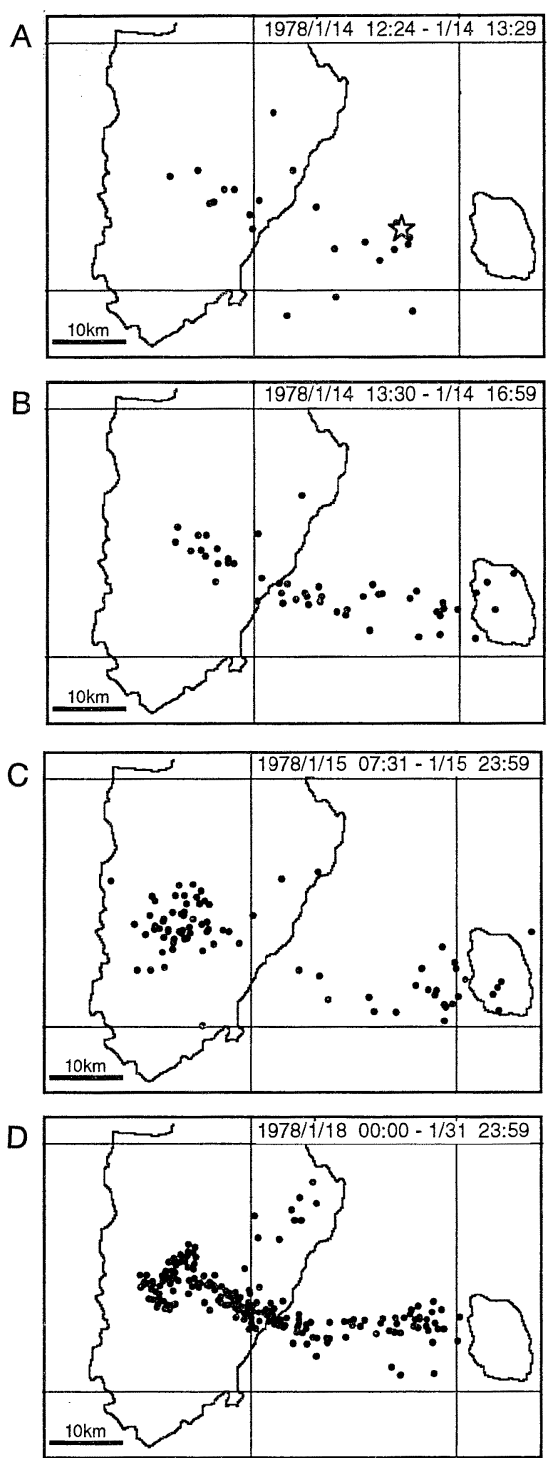

図 8 1978年伊豆大島近海地震の余震分布の 時空変化（津村ほか，1978）

$\mathrm{A} ：$ 月 14日 $12: 24 \sim 13: 29$ （星印は 1 月 14 日，12:24の本震の震央）

$\mathrm{B}:$ 1月14日 $13: 30 \sim 16: 59$

C : 1 月15日 $07: 31 \sim 23: 59$

$\mathrm{D}: 1$ 月18日 $~ 31$ 日

も，その北西端は YMTL 付近に限られており， それを越えて北西方の駿河トラフ軸付近へは広が っていない（石橋ほか，1975）。

古地磁気 : 伊豆半島の第四紀火山（時代的には 1.5 0.4Ma）の古地磁気偏角が，東伊豆/西伊豆
構造区閒で系統的に異なることが知られている (Kikawa et al., 1989; Koyama and Umino, 1991)。西伊豆構造区内の古地磁気偏角がやや時 計回り方向の異常を示すのに対し，東伊豆構造区 内の古地磁気偏角の多くは顕著な反時計回り方向 の異常を示し，両者の境界は東伊豆/西伊豆構 造 区境界に一致するように見える。このことは，東 伊豆構造区と西伊豆構造区が最近数十万年間に異 なる構造運動を被ったことを強く示唆している。

Kikawa et al. (1989) は，東伊豆/西伊豆構造 区間の古地磁気偏角異常の系統的な差を, 伊豆半 島の differential tilting（西伊豆構造区の西方〜 南西方への傾動，および東伊豆構造区の東方〜南 東方への傾動）によって説明した。これに対し， Koyama and Umino (1991) は, Kikawa et al. （1989）の示した東伊豆構造区の傾動角は第四 紀 の積算上下変動のパターンや地質構造と矛盾する ことを示し，東伊豆構造区内における反時計回り の block rotation の存在を主張した。

火山活動の性質 : 火山には複成火山と単成火山 があり，さらに単成火山には複成火山体の一部を なすものと，単成火山だけで火山群をなすもの (独立単成火山群) がある（中村，1986)。同じ火 道を何回も使用する複成火山は，地殼の側方拡大 が容易でないテクトニクス場に生じ，噴火のたび に新しい割れ目火道を開く(つまり，新たな割れ 目火道の幅分だけ地殼を伸張させる)。独立単成 火山群は，地殼の側方拡大が容易なテクトニクス 場に生じると考えられている。

独立単成火山群である東伊豆単成火山群は15万 年前頃から噴火を開始し，その分布は東伊豆構造 区内にほぼ限られる (Koyama and Umino, 1991 ; 小山, 1993：図 6)。これに対し，大島から 銭洲にかけての海域には伊豆大島, 新島, 神津島 などの複成の活火山が多く分布する。このことか ら，大島から銭洲にかけての海域を東伊豆構造区 と異なる volcanotectonic province（大島-銭洲構 造区）とみなし，東伊豆構造区を地殼の側方拡大 の容易な場，大島一銭洲構造区を 側方制約の大き な場とみなすことができる (Koyama and Umino，1991）。な扮，西伊豆構造区には更新世後期 
以降の从山がないため，現在どのような volcanotectonic province にあたるか不明である。

以上述べた数々の観察事実から，少なくとも東 伊豆/西㓅豆間には何らかの構造区境界があると みてよいだろう。つまり，構造区分としてのモデ ル 2 B はかなり有力な考え方だと思われる。大 島一銭洲溝造区に関してはデータ不足であり，東 伊豆構造区とのテクトニクス場の違いは現在のと ころ火山活動の性質のみによって示される。

モデル2 B が主張する東伊豆/西伊豆構造区分 のテクトニックな意味は何であろうか？塚原・ 池田 (1983) や Kikawa et al. (1989) は，駿河 トラフ下への沈み込み直前に生じるプレートの曲 りによニて東伊豆/西伊豆構造区境界で応力方位 が急変すると考えた。しかし，この考え方で地質 構造や地震活動の差まで説明するのは難しい。 Koyama and Umino (1991) は, モデル 2 C の考 え方を取り入れることによって，東伊豆構造区を 側方拡大:テクトニクスの場としてとらえ，西伊豆 構造区との違いを説明した。

\section{4) モ: デル $2 \mathrm{C}$}

伊豆半島内の構造区分に注目したモデル $2 \mathrm{~A} \sim$ $2 \mathrm{~B}$ と会やや異なり，モデル $2 \mathrm{C}$ は伊豆・小笠原 弧の外弧之内弧の性質の違いに注目する。モデル $2 \mathrm{C}$ は, 伊豆・小笠原弧を, 活動的火山弧である ゆえの浮揚性を備えた伊豆内弧と, 容易に沈み込 み可能な伊豆外弧との 2 つ構造区に分けること が重要と考える（図 9)。この考え方は，もともと Kaizuka (1975) や貝塚 (1984) によって主とし て伊豆・小笠原弧北部と関東地方の大地形を説明 するために提案されたものである。石橋 (1988) は，神奈川県西部においておよそ70年ごとに繰り 返す $M i$ 級の地震（神奈川県西部地震）のテクト ニクスを説明するため, 石橋 (1980) の西相模湾 スラストの概念を貝塚（1984）の考えと組み合わ せて修正し，伊豆外弧/内弧間のプレート内断裂 としての西相模湾断裂を提唱した。

Koyama and Umino (1991) も, 東伊豆構造 区のテクトニクスや東伊豆単成火山群の存在を説 明するために，西相模湾断裂の存在とその役割の 重要性を主張した。西相模湾断裂を含むプレート

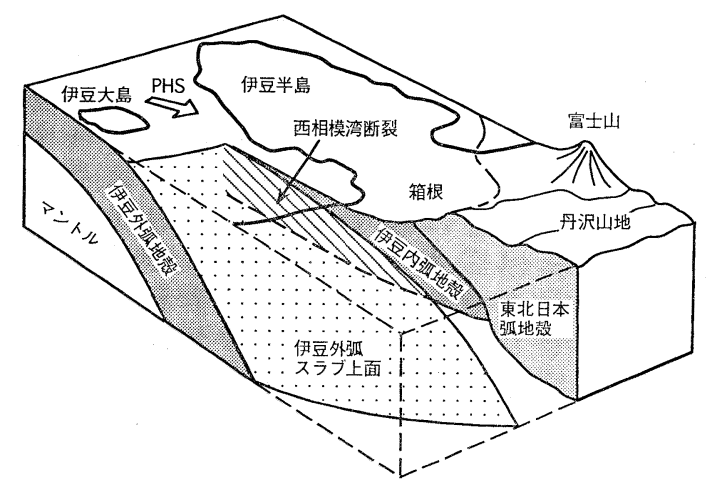

図 9 モデル $2 \mathrm{C}$ の例

石橋（1988）による伊豆・小笠原弧北端部のモデル の図を簡略化したもの. 伊豆・小笠原弧北端部を関 東平野下に沈み込む外弧と, 丹沢山地下にアンダー プレートする内弧に分けて考え，両者の間に生じる プレート内断裂として西相模湾断裂（図の斜線部） を考えた. 矢印 PHS は, 東北日本に対するフィリ ピン海プレートの相対運動方向.

幾何学を考えた場合, 断裂の上盤側にあたる伊豆 半島北東部の上部地殼にとっては, 北東側に拡 大するための障害が伊豆外弧の沈み込みによって ある程度取り払われた状況になっている（図 9 ， 10)。また，前節で述べた東伊豆構造区における 反時計回りの block rotation をおこすためには, 上部地款内に低角の滑り面の存在が必要である。 以上のようなプレート幾何学と滑り面の存在がマ グマ貫大にともなう北東方への地殼の側方拡大を 容易にし，東伊豆単成火山群を成立させたと考え るのが Koyama and Umino (1991) のモデル である。

海底地形, 歴史地震, 相模湾西部海域の地殼応 力方位と地款構造, 周辺テクトニクスからの要請 などを考えると，断裂の正確な位置や形状は別と して, 西相模湾断裂の存在そのものはかなり確か らしいと思われる(小山，1992)。しかし，断裂の 存在を疑う研究者も多い(たとえば,萩原，1993）。

\section{5）モデル $2 \mathrm{D}$}

モデル $2 \mathrm{D}$ は, モデル $2 \mathrm{~B}$ の東伊豆/西伊豆構 造区境界の北半分を重視し，東伊豆地域における 地款拡大に結びつける考え方である。Koyama and Umino (1991) の考えを引き継いだ小山 （1993）は，東伊豆単成火山群の噴火史から東伊 


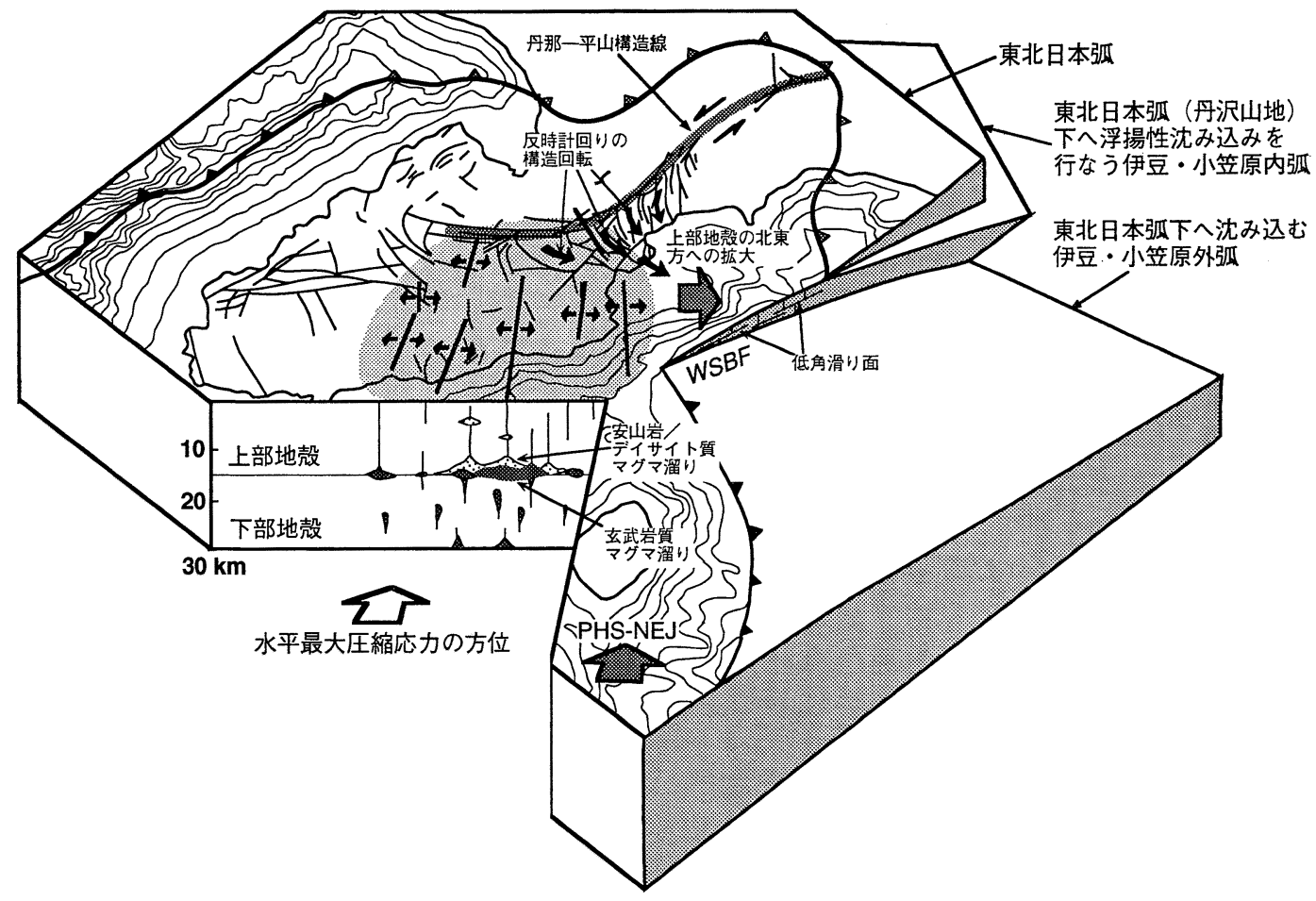

図 10 モデル $2 \mathrm{D}$ の例

小山（1993）による伊豆・小笠原弧北端部のモデル．東伊豆単成火山地域（陰影をつけた領域） を地款搪大域としてとらえ，その拉大運動を解消するトランスフォーム境界として丹那一平山構 造線を考えた. WSBF : 西相模湾断裂. 矢印 PHS-NEJ は，東北日本に対するフィリピン海 プレートの相対運動方向.

豆構造区に抢ける過去 15 万年間の平均地款拡大速 度をほぼ $0.5 \sim 1.5 \mathrm{~cm} /$ 年 と見積り，この地款拡 大によって生じる歪を解消する一種のトランスフ オーム断層として，丹那断層とその延長からなる 構造帯 (丹那一平山構造線 : Koyama and Umino （1991）の HTTL に相当）を位置づけた（図 10)。小山（1993）のモデルにしたがえば，東伊 豆単成火山地域, 丹那一平山構造線, 西相模湾断 裂，国府津-松田断層の四者に囲まれる伊豆地塊 北東部が，一種のマイクロプレートとして他の 伊豆地塊に対し 北北東進することになる。吉田 （1993）も小山（1993）と類似したモデルを考えて いるが，西相模湾断裂を重視していない点が異な る。

山岡ほか（1994）のモデルは，小山（1993） のモデルの一部をさらに発展させ，中部地方下の フィリピン海プレートスラブの形状までも説明
しようとした野心的なモデルである。山岡ほか （1994）は，東伊豆単成火山地域から伊豆大島火 山までをひとつの連続的な地殼拡大域としてとら え, この桩大域が第四紀後期を通じて南東方に伝 播（propagate）してきたと考えた。そして，こ の伝播性拡大によって生じた地殼の裂け目が富士 山下のフィリピン海プレートスラブの久如と, 愛 知県下のスラブの重複をつくったと説明した。

\section{V. まと め}

以上，伊豆・小笠原弧北端部に扮ける現在およ び第四紀後期のテクトニクスの統一的理解を試み たモデルを整理・紹介し，問題点の指摘と議論を 行なった。要点を以下に述べる。

1. これ亲で提案された伊豆・小笠原弧北端部 のテクトニックモデルは，伊豆・小笠原弧北端部 を単一構造区とみなすモデル（モデル 1 ），複数 
の構造区の集合体とみなし構造区ごとにやや異な るテクトニクスを考えるモデル（モデル2），の 2 つに大きく区分できる。

2. モデル 1 の中には, 相模・駿河両トラフで の沈み込みにともならプレートの曲りを重視する モデル (モデル $1 \mathrm{~A})$ ，伊豆・小笠原弧と本州弧 の衝突による圧縮力と相模トラフ下に沈み込んだ プレートのスラブプルカを重視するモデル（モデ ル $1 \mathrm{~B})$ ，の 2 種類がある。

3. モデル 2 の中には, 伊豆半島の北部と南部 で異なる構造区を考えるモデル（モデル $2 \mathrm{~A}$ ）, 伊豆半島を北北東一南南西に縦断する構造線の東 西で異なる構造区を考えるモデル（モデル $2 \mathrm{~B}$ ), 伊豆・小笠原弧北端部を伊豆内弧と伊豆外弧の 2 つの構造区に分けるモデル（モデル $2 \mathrm{C}$ ), 東伊豆 単成火山池域を地款拡大域, 丹那断層とその延長 を地款拡大にともならトランスフォーム断層とし てとらえるモデル（モデル $2 \mathrm{D}) ，$ の 4 種類があ る。

4. モデル $2 \mathrm{~A}$ は，調和的でない観測事実が 多い点でやや問題があると思われる。構造区分と しては，洰デル $2 \mathrm{~B}$ ののがより確からしい。モ デル $2 \mathrm{C}$ は西相模湾断裂を重視した立場をとる が，断裂の存在そのものの是非・位置・形状に関 しては様々な議論がある。東伊豆構造区内の地殼 桩大という新たな発想にもとづくモデル $2 \mathrm{D}$ は, 今後の発展の可能性を秘的ている。

西相模湾断裂の是非の議論や神奈川県西部地震 のテクトニクスに関する筆者の見解については， 紙数の関係から機会をあらためて述べる。

\section{謝 辞}

石橋克彦抢よび医名查読者の両氏からいただいたコメ ントは, 本論文の改善に大いに役立ちました。ここに記 して感謝します。

\section{文献}

Asano, S., Yoshii, T., Kubota, S., Sasaki, Y., Okada, H., Suzuki, S., Masuda, T., Murakami, H., Nishide, N. and Inatani, H. (1982): Crustal structure in Izu Peninsula, Central Japan, as derived from explosion seismic observations 1. MishimaShimoda profilc. J. Phys. Earth, 30, 367-387.
藤井陽一郎（1977）：1930年および1976年前後の 伊豆東 方線の活動. 地震 $2, \mathbf{3 0}, 389-400$.

萩原幸男 (1993) : 「神奈川県西部地震」研究の現状と展 望. 地学雑誌, 102, 337-340.

星野一男 (1984) : 応力場, 活断層と南部フォッサマグ ナのネオテクトニクス. 第四紀研究， 23，117-128.

星野一男・橋本知昌・松田時彦 (1977) : 伊豆半島南 部 の活断層について. 地質調查所特別報告, No. 6, 7382.

星野一男・橋本知昌・松田時彦 (1978) : 伊豆半島活 断 層図. 構造図 4 , 地質調查所.

Ida, Y. (1991): Interpretation of seismic and volcanic activities in the Izu block in relation to collision tectonics. J. Phys. Earth, 39, 421-440.

石橋克彦 (1977) : 「西相模湾地震」の可能性と東海地震 との関連. 地震予知連絡会東海部会編: 地震予知連絡 会東海部会資料. 建設省国土地理院，53-68.

石橋克彦 (1980): 伊豆半島をめぐる現在のテクトニク ス. 月刊地球, $2,110-119$.

石橋克彦 (1988): “神奈川県西部地震” と地震予知 I, II. 科学, 58, 537-547; 771-780.

石橋克彦 (1992) : 「大磯型地震」と相模トラフ巨大地震 (試論). 月刊地球，号外 No. 5, 73-77.

石橋克彦・ 未広 潔・稲谷栄已 - 松崎孝文 - 浅田敏 (1975) : 1974年伊豆半島沖地震の超高感度余震観測.

土 隆一編 : 1974年伊豆半島沖地震災害調查研究報告. 昭和 49 年度文部省科学研究費自然災害特別研究報告書, 21-26.

石井 紘(1989): 最近の伊豆半島の隆起について (19801988). 東京大学地震研究所畄報, 64, 313-324.

石井 紘 (1992): 伊東沖海底噴火前後の伊豆半島の特 徵的上下変動. 東京大学地震研究所彙報, 67, 67-77.

Kaizuka, S. (1975) : A tectonic model for morphology of arc-trench systems, especially for the echelon ridges and mid-arc faults. Japan. J. Geol. Geogr., 45, 9-28.

貝塚㤽平 (1980): 伊豆バーと千島外弧バーの第四紀 変 動図. 月刊地球, 2, 155-156.

貝塚爽平 (1984) : 南部フォッサマグナに関連する地形 とその成立過程. 第四紀研究，23，55-70.

狩野謙一 (1983) : 安山岩質海底火山の浅部構造——伊 豆半島南端部の新第三系白浜層群に見られる例一一. 静岡大学地球科学研究報告, 8, 9-37.

笠原敬司 (1985): プレートが三重会合する関東・東海 地方の地殼活動様式. 国立防災科学技術センター研究 報告, 35, 33-137.

Kikawa, E., Koyama, M. and Kinoshita, H. (1989) : Paleomagnetism of Quaternary volcanics in the Izu Peninsula and adjacent areas, Japan, and its tectonic significance. J. Geomag. Geoelectr., 41, 175-201.

小林洋二 (1980): “Tectonic Stress Province” の存 在について. 月刊地球, 2, 569-572.

小山真人 (1986): 伊豆半島の地史と足柄 - 大磯地域 の 更新世. 月刊地球，8，743-752. 
小山真人 (1988): 伊豆半島の過去と現在. 荒牧重雄・ 新妻信明編 : 陸上学術ボーリング候補地集 I . 陸上学 術ボーリングワーキンググループ，1-32.

小山真人 (1992): 西相模湾断裂の再検討と八王子構 造 線の成因. 地球惑星科学関連学会1992年合同大会共通 セッション・シンポジウム予稿集，p. 344.

小山真人 (1993) : 伊豆半島の火山とテクトニクス. 科 学, 63, 312-321.

Koyama, M. and Umino, S. (1991): Why does the Higashi-Izu monogenetic volcano group exist in the Izu Peninsula?: Relationships between late Quaternary volcanism and tectonics on the northern tip of the Izu-Bonin arc. J. Phys. Earth, 39, 391-420.

小山真人 - 新妻信明 - 狩野謙一 - 高木主介 - 内村竜一 吉田智治・唐沢 譲・田邊裕高 (1992) : 駿河トラフ 伊豆側斜面の地質とテクトニクスー「しんかい2000」 第579潜航の成果—. 海洋科学技術センター試験 研 究報告, 第 8 回「しんかい」研究シンポジウム特集, 145-161.

Matsuda, T. (1978): Collision of the Izu-Bonin arc with central Honshu: Cenozoic tectonics of the Fossa Magna. Japan. J. Phys. Earth, 26, S 409-S 421.

松田時彦 (1985): 大磯型地震について. 月刊地球, 7, 472-477.

松田時彦 (1993) : 相模湾北西部地域の地震テクトニク ス. 地学雑誌, 102, 354-364.

茂木清夫 (1977) : 伊豆・東海地域の最近の地殼活動の 一解釈. 東京大学地震研究所彙報, 52, 315-331.

中村一明 (1980): 伊豆のテクトニクスとプレートの曲 り. 月刊地球, 2, 94-102.

中村一明 (1986) : 火山とプレートテクトニクス. 火山, 第 2 集，30,S 1-S 16.

中村一明・島崎邦彦 (1981) : 相模・駿河トラフとプレ 一トの沈み込み. 科学, 51, 490-498.

Nakamura, K., Shimazaki, K. and Yonekura, N. (1984): Subduction, bending, and eduction Present and Quaternary tectonics of the northern border of the Philippine Sea plate. Bull. Soc. Geol. France, 26, 221-243.

中野佳昭・杉田 理 - 井口博夫 - 小林洋二 (1980) : 岩 脈群からみた伊豆半島のテクトニクス. 月刊地球， 2 , 103-109.

大河内直彦 (1990) : 相模湾の活構造とテクトニクス. 地学雑誌, 99, 458-470.

Somerville, P. (1978): The accommodation of plate collision by deformation in the Izu block, Japan. Bull. Earthq. Res. Inst., Univ. Tokyo, 53, 629648.

杉村 新 (1972): 日本付近におけるプレートの境界. 科学, 42, 192-202.

杉山雄一・下川浩一・坂本 烹・秦 光男 (1982) : 静
岡地域の地質. 地域地質研究報告 5 万分の 1 図幅, 地 質調查所.

多田 堯 (1977) : 熱海一沼津構造線の提唱. 地震 2 , 30, 374-377.

Tada, T. and Asano, S. (1983): Anomalous crustal uplift and crustal structure in the Matsushiro and the Izu Peninsula earthquake swarm regions. Tectonophysics, 97, 241-250.

Tada, T. and Sakata, S. (1977): On a fault model of the 1923 Great Kanto earthquake and its geotectonic implication. Bull. Geogr. Surv. Inst., 22, 103-120.

塚原弘昭・池田隆司（1983）: 関東 - 東海地域の 地殼応 力. 地震 $2, \mathbf{3 6}, 571-586$.

Tsukahara, H. and Ikeda, R. (1987): Hydraulic fracturing stress measurements and in-situ stress field in the Kanto-Tokai area, Japan. Tectonophysics, 135, 329-345.

津村建四朗・唐鎌郁夫・荻野 泉・高橋正 義 (1978): 1978年伊豆大島近海地震前後の地震活動. 東京大学地 震研究所葷報，53，675-706.

恒石幸正・杉山雄一（1978）：駿河卜ラフを横断する 駿 豆断層. 地震予知連絡会会報，20，138-141.

Ukawa, M. (1991) : Collision and fan-shaped compressional stress pattern around the Izu block at the northern edge of the Philippine Sea plate. J. Geophys. Res., 96, 713-728.

Ukawa, M., Eguchi, T. and Fujinawa, Y. (1988): Seismic activity in the subducting Philippine Sea plate along the Suruga trough revealed by OBS observation. J. Phys. Earth, 36, 69-87.

Yamada, E. (1977): Stratigraphy and geological structure of the Neogene formations, southeastern part of the Izu Peninsula, Japan. Bull. Geol. Surv. Japan, 28, 711-733.

山岡耕春・大井田 徹 - 山崎文人 (1994)：伊豆周辺の 地殼活動と中部東海地域に沈み込んだフィリピン海プ レートの形状. 地学雑誌, 103，567-575.

山崎晴雄 (1985): 足柄平野の地質と地殼変動. 月刊地 球， 7, 466-472.

Yamazaki, H. (1992): Tectonics of a plate collision along the northern margin of Izu Peninsula, central Japan. Bull. Geol. Surv. Japan, 43, 603657.

山崎晴雄 (1993) : 竍関東の地震テクトニクスと 国 府 津・松田断屬の活動. 地学雑誌，102，365-373.

吉田明夫 (1985): 伊豆半島及びその周辺海域の地震活 動にみられる非重畳性と移動性. 地震 2，38， 125136.

声田明夫（1993）: 神奈川県西部およびその周辺の地震 活動とテクトニクス. 地学雑誌, 102，407-417.

(1994年6月13日受付，1994年 7 月18日受理) 